\title{
Chemical Control of Pre Harvest Fruit Drop in Nagpur Mandarin (Citrus reticulata) of Chhindwara District of Madhya Pradesh, India
}

\author{
Omnarayan Verma ${ }^{1}$, Bhupendra Thakre $^{2 *}$ and Uttam soni ${ }^{1}$
}

${ }^{1}$ (Horticulture) Zonal Agricultural Research Station, JNKVV, Chhindwara, MP 480001, India

${ }^{2}$ (Plant Pathology) Zonal Agricultural Research Station, JNKVV, Chhindwara, MP 480001, India

*Corresponding author

\begin{abstract}
A B S T R A C T
\section{Keywords}

Citrus, Nagpur

Mandarin, Fruit drop, Growth regulators, Plant growth

Article Info

Accepted:

16 December 2017

Available Online:

10 January 2018

Orchard experiments were carried out in JNKVV, Zonal Agricultural Research Station, Mohagaon Farm at Sausar Block of Chhindwara District of Madhya Pradesh with the objective of Chemical Control of pre harvest fruit drop in Nagpur Mandarin (Citrus reticulala) on reducing fruit drop. The experiment was laid out in RBD in Nine treatments and two factors one is at pea stage second one is Gravel stage with tree replication. Season for experiment was selected Zaid (Ambia bahar) with Different concentration levels of Treatments in the 2013/2014 season. The application of Growth regulator in the orange fruit orchard can be helpful in controlling pre-harvest fruit drop, hence increasing yield and giving good returns to the growers. Application of growth regulator NAA $20 \mathrm{ppm}$ at pea and gravel stage increased the fruit retention to $45.00 \%$ as compared to $24.00 \%$ in control. Due to Urea $2.00 \%$ spray 100 fruit weight was increased from $15.33 \mathrm{Kg}$ to 16.70 Kg. Plant Growth Regulators (PGR's) are used on citrus worldwide and active research programs are in progress in most citrus-growing countries. Principal uses for PGR's on citrus are for control of fruit maturity, reduction of fruit drop, prevention of rootstock sprouting, fruit thinning, preservation of fresh fruit peel quality, and control of the abscission process for harvesting.
\end{abstract}

\section{Introduction}

Citrus is an economically important crop of India, for its highly nutritive and commercial value. Phonology is one of the important aspects of citrus that needs to be studied. The information about phonological events and their variability can provide valuable data for planning, organizing and timely execution of certain standard management and cultural activities that require advanced information on the dates of specific stages of crop development.

Whether you're growing your citrus tree for the fruit it produces or as an ornamental specimen for its form, foliage, flowers and fruit, you're likely alarmed when the citrus fruits begin to drop prematurely. Some amount of fruit drop at a certain stage of development is normal, but an excessive drop of older fruit could indicate a number of 
problems. In cause of normal fruit drop Citrus trees normally drop some of their young fruits as a means to thin the fruit out and devote resources to the development of the fruits that remain. Beginning soon after blossom drop, and ending when the fruit has a diameter of about $1 / 2$ inch, it is normal if approximately 80 to 90 percent of the fruit falls off the tree. A small amount of fruit may continue to drop as it grows on the tree.

A number of nutrient deficiencies can contribute to excessive fruit drop, and identifying the exact nutrient deficiency means you can apply the right fertilizer to correct the deficiency. A nitrogen deficiency appears first as a yellowing of older leaves, while a magnesium deficiency appears as a yellowing between veins on older leaves and leaf drop. Inadequate zinc causes young leaves to be abnormally small and have yellow blotches between veins, particularly on the south-facing side of the canopy. A citrus tree lacking manganese has leaves that turn a lighter green between leaf veins. An iron deficiency, most prevalent in alkaline soils with excessive moisture, appears as interveinal yellowing.

In heavy fruiting years, low potassium levels can impact fruit drop. Good water management is crucial to avoid excessive fruit drop and other citrus tree problems. Excessive watering, poorly drained soils or drought stress can lead to fruit drop. As a general rule, citrus trees prefer a slow, deep watering every five to 14 days during dry, hot weather, depending on the citrus tree's age, and every 14 to 30 days during cool, wet weather, or whenever the soil 6 inches below the surface near the tree feels dry to the touch. Excessive pruning can stress the citrus tree and remove too much of its foliage, forcing fruit drop. A severe pest infestation can also stress the tree enough to cause fruit drop. Sudden changes in temperature, particularly when high temperatures occur at or shortly after fruit set, can cause fruit drop. Where citrus trees are planted in poorly drained or low-lying sites, fruit drop caused by brown rot can become problematic following extended periods of wet and warm weather in late summer and fall.

\section{Materials and Methods}

The experiment was conducted at Jawaharlal Nehru Krishi Vishwa Vidyalaya, Zonal Agriculture Research Station, Mohagaon Farm, Sausar Block of Chhindwara District Of Madhya Pradesh during 2013-14.The experiment was laid out in Randomized Complete Block Design (RBD) in Nine treatments and two factor one is At pea stage second one is Gravel stage with tree replication. Season for experiment was selected Zaid (Ambia bahar). The flowing treatment used

$\mathrm{T}_{1=}$ NAA 20 ppm Spray

$\mathrm{T}_{2}=\mathrm{NAA} 20 \mathrm{ppm}+$ Carbendazim $0.2 \%$ spray

$\mathrm{T}_{3}=\mathrm{NAA} 10 \mathrm{ppm}+2,4-\mathrm{D} 10$ ppm Spray

$\mathrm{T}_{4}=\mathrm{NAA} 20 \mathrm{ppm}+$ Urea $2.0 \%$

$\mathrm{T}_{5}=$ NAA $20 \mathrm{ppm}+$ Streptocycline $30 \mathrm{ppm}$ Spray

$\mathrm{T}_{6}=$ Urea $2.0 \%$

$\mathrm{T}_{7}=$ Streptocycline $30 \mathrm{ppm}$ Spray

$\mathrm{T}_{8}=$ Carbendazim $0.2 \%$ spray

$\mathrm{T}_{9}=$ Control (Water) $0.2 \%$ Spray

The data recorded on different parameters were subjected to analysis of variance (ANOVA) techniques observe the difference, between the different treatment as well as their interaction. 


\section{Results and Discussion}

The data regarding the fruit drop as affected by different orientations were collected and analyzed. It is clear from the data presented in Table 1 that orientation had non-significant difference with reference to fruit drop. In this experiment application of growth regulators, fungicides and nitrogen (Urea farm) have not show any significant difference. However the maximum fruit retention 45.00 was observed with the application NAA $20 \mathrm{ppm}$ at pea and gravel stage. Followed by NAA $20 \mathrm{ppm}+$ Carbendazim $0.2 \%(43.67 \%)$, NAA $10 \mathrm{ppm}$ $+2,4-\mathrm{D} 10 \mathrm{ppm}(43.33 \%)$ and NAA $20 \mathrm{ppm}$ + Urea $2.0 \%(41.00 \%)$ while application of simple water spray gave $24.00 \%$ fruit retention only. With the application of Nitrogen in the form of Urea $2.0 \%$ spray increased the 100 fruits weight to $16.70 \mathrm{Kg}$ in comparison $15.33 \mathrm{Kg}$ with the application of simple water spray.

Table.1 Effect of growth regulators, fungicides and nitrogen on fruit retention and fruit weight in Nagpur Mandarin

\begin{tabular}{|c|c|c|c|c|c|}
\hline S.No. & Treatment & $\begin{array}{l}100 \text { Fruit } \\
\text { wt./ Tree Kg }\end{array}$ & $\begin{array}{c}\text { Av. Fruit } \\
\text { set / panicle } \\
\text { before } \\
\text { Spry }\end{array}$ & $\begin{array}{l}\text { Av. Fruit set } \\
\text { / panicle } \\
\text { After Spry }\end{array}$ & Percentage \\
\hline 01 & NAA 20 ppm Spray & 16.33 & 2.33 & 1.06 & 45.00 \\
\hline 02 & $\begin{array}{c}\text { NAA } 20 \text { ppm + } \\
\text { Carbendazim } 0.2 \% \text { spray }\end{array}$ & 16.23 & 2.67 & 1.17 & 43.67 \\
\hline 03 & $\begin{array}{l}\text { NAA } 10 \text { ppm + 2,4-D } 10 \\
\text { ppm Spray }\end{array}$ & 16.66 & 2.47 & 1.10 & 43.33 \\
\hline 04 & NAA 20 ppm + Urea $2.0 \%$ & 16.50 & 2.43 & 1.00 & 41.00 \\
\hline 05 & $\begin{array}{c}\text { NAA } 20 \mathrm{ppm}+ \\
\text { Streptocycline } 30 \mathrm{ppm} \\
\text { Spray }\end{array}$ & 16.16 & 2.33 & 1.00 & 40.33 \\
\hline 06 & Urea $2.0 \%$ & 16.70 & 2.57 & 0.70 & 27.33 \\
\hline 07 & $\begin{array}{c}\text { Streptocycline } 30 \mathrm{ppm} \\
\text { Spray }\end{array}$ & 15.66 & 2.23 & 0.60 & 27.00 \\
\hline 08 & Carbendazim $0.2 \%$ spray & 15.66 & 2.43 & 0.57 & 23.33 \\
\hline 09 & Control $0.2 \%$ Spray & 15.33 & 2.50 & 0.57 & 24.00 \\
\hline & $\mathrm{SEm}_{+}^{+}$ & 0.046 & - & - & 8.328 \\
\hline & C.D.@5\% & NS & - & - & NS \\
\hline & C.V. $\%$ & 4.95 & - & - & 41.21 \\
\hline
\end{tabular}


Fig.1 100 fruit weight / tree, average fruit set / panicle before spray, average fruit set / panicle after spray

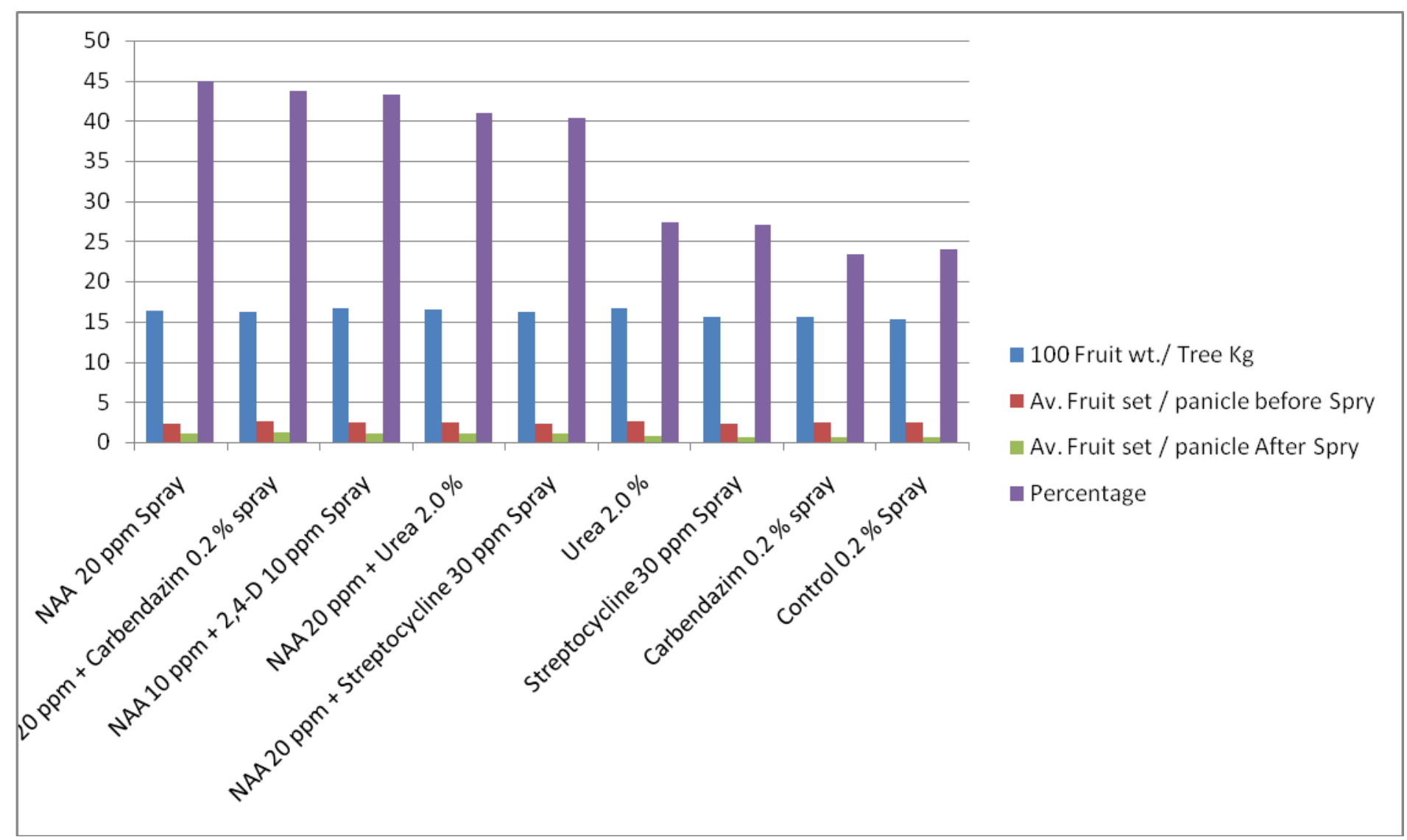

It is general observation that most of the citrus fruits drop due to formation of abscission layer and fungal disease. This may be due to shortage and imbalance of some hormones and some pathological and bacterial problem. It has been also reported by several workers that this pre harvest fruits drop in citrus can be very effectively controlled by spraying of hormones and used of some fungicides.

The application of Growth regulator in the orange fruit orchard can be helpful in controlling pre-harvest fruit drop, hence increasing yield and giving good returns to the growers. Application of growth regulator NAA $20 \mathrm{ppm}$ at pea and gravel stage increased the fruit retention to $45.00 \%$ as compared to $24.00 \%$ in control (Fig. 1). Due to Urea $2.00 \%$ spray 100 fruit weight was increased from $15.33 \mathrm{Kg}$ to $16.70 \mathrm{Kg}$.

\section{Acknowledgement}

We are very thankful to Professor Dr. S.R. Dharpure (Ex - Associate Director Research / Coordinator TMC - Chhindwara) and Dr. D.N. Nandeker (Coordinator TMC Chhindwara) Jawaharlal Nehru Krishi Vishwa Vidyalaya, Zonal Agriculture Research Station, for their kind supervision and help in designing and executing the experiment

\section{References}

Agusti, M., Garcia-Mari, F. and Guardiola, J. L. 1982. "Gibberellic acid and fruit set in sweet orange", Scientia Hort. 17(3): 
257-264.

Bangerth, F. and Schroder, M. 1994. "Strong synergistic effects of gibberellins with the synthetic cytokinin N-(2- chloro-4pyridyl)-N-phenyl urea on parthenocarpic fruit set and some other fruit characteristics of apple", Plant Growth Regulation, 15(3), 293-302.

Catrso, P. R. C., Filho, A. C. V. and Medina, C. L. 1998. Effect of fungicides, Gibberellic acid and growth stimulants on sprouting and fruit set in 'Pera' (Citrus sinensis L. Osbeck) orange tree. ISHS Acta Hort. 463, 1 (26).

Gillaspy, G., H.B. David and W. Gruissem. 1993. Fruits: a developmental perspective. J. Plant Cell, 5: 1439-1451.

Goldschmidt, E. E., Aschkenazi, N., Herzano, Y., Schaffer, A.A. and Monselise, S.P. 1985. A role for carbohydrate levels in the control of flowering in citrus, 26 (2), 159-166.

Goldschmidt, E. E., Tamim, M. and Goren, R. 1998. Gibberellins and flowering in citrus and other fruit trees: A critical analysis, ISHS Acta Hort. 463, 1 (26).

Gomez, C.A., J. Mehouachi, F.R. Tadeo, M.E. Primo and M. Talon. 2000. Hormonal regulation of fruit let abscission induced by carbohydrate shortage in citrus. Plant, 210: 636-643.

Gomez, C.A., Mehouachi, J., Tadeo, F.R., Primo, M.E. and Talon, M. 2000. Hormonal regulation of fruit let abscission induced by carbohydrate shortage in citrus, Plant, 210, 636-643.

Guardiola, J. L., Barries, M. T., Albert, C. and Garcia-Louis, A. 1993. Effect of exogenous growth regulators on fruit development in Citrus unshiu, Ann. of Bot. 71 (2), 169-176.

Kassem1, H. A., El-Kobbia, A. M., Marzouk, H. A. and El- Sebaiey, M. M. 2010. Effect of foliar sprays on fruit retention, quality and yield of Costata persimmon trees, Emir. J. Food Agric. 22 (4), 259-
274.

Khalid, S., Malik, A. U., Khan, A. S. and Jamil, A. 2012. Influence of exogenous applications of Plant Growth Regulators on fruit quality of young 'Kinnow' Mandarin (Citrus nobilis $\times$ C. deliciosa) trees, International J. of Agric. and Biology. 14(2), 229-234.

Liao, H.L., Chen, H., and Chung, K.R. 2006. Plant hormone inhibitors for reducing post bloom fruit drop of citrus, Proc. Fla. State Hort. Soc., 119, 78-81.

Liao, H.L., H. Chen and K.R. Chung. 2006. Plant hormone inhibitors for reducing postbloom fruit drop of citrus. Proc. Fla. State Hort. Soc., 119: 78-81.

Majumdar, P.K. and S.K. Mukherjee. 1961. Studied on the variability of sex expression in mango (Mangifera indica L.). Indian J. Hort., 9: 12-18.

Marcelle, R. D. 1984. Effect of GA3, BA and growth retardants on fruit set in the pear cultivar Doyenné du Comice, ISHS Acta Hort. 149, 1 (27).

Mesejo, C., Reig, C., Martínez-Fuentes, A. and Agusti, M. 2010. Parthenocarpic fruit production in loquat (Eriobotrya japonica Lindl.) by using Gibberellic acid, Scientia Hort. 126 (1), 37-41.

Modise, D.M., A.S. Likuku, M. Thuma and R. Phuti. 2009. The influence of exogenously applied 2,4- dichlorophenoxyacetic acid on fruit drop and quality of navel oranges (Citrus sinensis L.). Afric. J. Biotech., 8(10): 2131-2137.

Monselise, S.P. and R. Goren. 1978. The role of internal factors and exogenous control in flowering, peel growth, and abscission in citrus. Hort. Sci., 13: 134139.

Parmar, H. S. and Kar, A. 2008. "Medicinal values of fruit peels from Citrus sinensis, Punica granatum and Musa paradisiaca with respect to alternations in tissue peroxidation and serum concentration of glucose, insulin and 
thyroid hormones, J. Medicinal Food, 11(2), 376-381.

Ramezani, S. and Shekafandeh, A. 2008. "Roles of Gibberellic acid and zinc sulphate in increasing size and weight of olive fruit, African J. of Biotech. 8 (24).

Reig, C., Farina, V., Volpe, G., Mesejo, C., Martínez-Fuentes, A., Barone, F., Calabrese, F. and Agusti, M. 2011. "Gibberellic acid and flower bud development in loquat (Eriobotrya japonica Lindl.), Scientia Hort. 129 (1), 27-3.

Saleem, B. A., Malik, A. U., Pervez, M. A. and Khan, A. S. 2008. "Growth regulators application affects vegetative and reproductive behavior of 'Blood Red' Sweet orange, Pak. J. Bot. 40 (5), 2115-2125.

Sharna, T.R., P.K. Niar and M.K. Nema. 1990. Effect of foliar spray of urea, KNO3 and NAA on fruiting behaviour of mango cv. 'Langra'. Orissa J. Hort., 18 (1and2): 42-47.

Steel, R.G.D., J.H. Torrie and M.A. Boston. 1997. Principles and Procedures of statistics. 2nd Ed. McGraw-Hill Book Co. Inc. USA: $633 \mathrm{pp}$.

Stover, E.W. 2000. Reducing post-bloom fruit drop through the use of plant growth regulator to concentrate bloom. Hort. Sci., 53: 496-497.

Taiz, L. and Zeiger, E. 2011. "A companion to plant physiology, chapter 20, Gibberellins; regulators of plant height, 5 (462).

Tominaga, S. 1998. "GA sprays delay and reduce physiological fruit drop in Ponkan mandarin (Citrus reticulata Blanco), ISHS Acta Hort. 463, 301-305.

Tominaga, S. 1998. GA sprays delay and reduce physiological fruit drop in Ponkan mandarin (Citrus reticulata Blanco). Acta Hort. (ISHS), 463: 301305.

Vasilakakis, M., A. Alexandridis, S. El. Fadl and K. Anagnostou. 1996. Effect of substrate (New or Used Perlite), plant orientation on the column and irrigation frequency on strawberry plant productivity and quality. CIHEAMOptions Mediterraneennes, 31: 357363.

Yamamura, H., Matsui, K. and Matsumoto, T. 1989. "Effects of gibberellins on fruit set and flower-bud formation in unpollinated persimmons (Diospyros kaki), Scientia Hort. 38(1-2), 77-86.

\section{How to cite this article:}

Omnarayan Verma, Bhupendra Thakre and Uttam soni. 2018. Chemical Control of Pre Harvest Fruit Drop in Nagpur Mandarin (Citrus reticulata) of Chhindwara District of Madhya Pradesh, India. Int.J.Curr.Microbiol.App.Sci. 7(01): 2258-2263.

doi: https://doi.org/10.20546/ijcmas.2018.701.273 